Trivent Publishing

(C) The Authors, 2016

Available online at http://trivent-publishing.eu/

Series: Philosophy, Communication, Media Sciences

Volume: Communication Today: An Overview from Online Journalism to Applied Philosophy

\title{
The Role of the Court of Justice of the European Union's Rulings in Matters of Asylum and Immigration
}

\author{
Lavinia Andreea Bejan \\ SOP HRD/159/1.5/S/133675 Project, Romanian Academy Iasi Branch, Romania
}

\begin{abstract}
By analyzing relevant case-law of the Court of Justice of the European Union, such as C-405/07 Elgafaji, C-31/09 Bolbol, C-411/10 N.S., joined with C-493/10 M. E. and others, C-4/11 Kaveh Puid, the present paper aims to clarify the manner in which the jurisprudence of the Court of Justice of the European Union contributed to the interpretation of European Union legislation regarding asylum and migration, and, subsequently, how it referred to other relevant international or regional treaties. Also, the paper aims to offer a fair assessment of the importance of the rulings of the Court in matters of asylum and immigration.
\end{abstract}

\section{Keywords}

1951 Geneva Convention on the Status of Refugees; European Union; right of asylum; immigration; the European Court of Human Rights; the Court of Justice of the European Union; Dublin Regulations; the Qualification Directive; preliminary rulings.

This is an Open Access article distributed in accordance with the Creative Commons Attribution Non Commercial (CC-BYNC-ND 4.0) license, which permits others to copy or share the article, provided original work is properly cited and that this is not done for commercial purposes. Users may not remix, transform, or build upon the material and may not distribute the modified material (http://creativecommons.org/licenses/by-nc/4.0/)

DOI: $10.22618 /$ TP.PCMS.20164.349022 


\section{Introduction}

The multiplication of the number of migrants from third-countries within the borders of the European Union in recent years raised a number of important issues regarding the overall functioning of the EU, from an institutional perspective. Some concern the deficiencies of EU legislation and its application in matters of asylum and immigration, as well as the shy attempts at better regulating and enforcing the relevant existing rules, some - the lack of appropriate reactions and responses on the institutional level.

If we are to consider Jean Claude Juncker's first State of the Union (September 9, 2015), and the claimed promise that "the Commission will come forward with a well-designed legal migration package in early 2016," legislative reform does not seem to occur too soon. At the same time, on September 23, 2015, the European Commission issued a Communication to the European Parliament, the European Council and the Council regarding "Managing the Refugee Crisis: immediate operational, budgetary and legal measures under the European Agenda of Migration," stating both that the Dublin Regulation needs to be revised, and that a special attention "needs to be paid to Greece to prioritize the normalization of the situation and a return to the Dublin system within the next six months" - the impossibility of transfers back to Greece as "state responsible" according to Dublin came through a judicial channel.

In this context, an analysis of the role of the Court of Justice of the European Union in matters of asylum and immigration is necessary (and shall be done particularly using qualitative research methods such as historical research, documentary analysis, case studies on the most relevant decisions of the Court of Justice of the European Union in terms of asylum and migration), given the fact that the Court has the possibility to interpret EU legislation (through preliminary rulings) and to ensure that the EU legislation is applied in the same manner in all EU member states, to annul EU pieces of legislation that breach fundamental rights or the Treaties, to sanction EU institutions and so on.

The paper will discuss the compliance by EU law with the 1951 Geneva Convention relating to the Status of Refugees as established by the Court, questions regarding the serious and individual threat to the life of a person in light of accepting the request for subsidiary protection, questions regarding identity controls in border areas, as well as the issue of the Dublin system enforcement when the according responsible state shows systemic deficiencies in the asylum procedure and in the reception conditions of the asylum seekers that amount to substantial grounds for believing that the asylum seeker would face a real risk of being subjected to inhuman or degrading treatment or other fundamental rights. Moreover, the paper aims to identify possible manners in which the decisions of the Court could be taken into consideration in situations regarding the current migrant crisis (for instance, could transfers back to Hungary, for instance, or other states of entry for migrants be suspended on the same grounds transfers were suspended towards Greece?). Finally, the importance of the Court of Justice of the European Union in matters regarding asylum and immigration is to be fairly assessed.

\section{The 1951 Geneva Convention and European law}

On the international, general level (within the United Nations framework), the 1951 Geneva Convention relating to the Status of Refugees (most commonly referred to as the 1951 Refugee Convention) is the most important legal instrument regarding the protection of this vulnerable category of individuals. The Convention defines the refugee as a person who, "owing to well-founded 
fear of being persecuted for reasons of race, religion, nationality, membership of a particular social group or political opinion, is outside the country of his nationality and is unable or, owing to such fear, is unwilling to avail himself of the protection of that country; or who, not having a nationality and being outside the country of his former habitual residence as a result of such events, is unable or, owing to such fear, is unwilling to return to it."1 The temporal and spatial limitation that the 1951 text contained ("as a result of events occurring before 1 January 1951," ${ }^{2}$ further explained as: either "events occurring in Europe before 1 January 1951" or "events occurring in Europe or elsewhere before 1 January 1951"3) were eliminated by the 1967 Protocol to the Convention, hence no longer apply, and the Convention now has a potentially universal character. Moreover, many of its provisions are now considered customary law, which should solve the issue of its application regarding non-party states - as of April 2015, there are 145 states parties to the Convention, 146 to the 1967 Protocol, and 142 to both. ${ }^{4}$ The 1951 Convention establishes principles of utmost importance regarding refugees, such as non-discrimination ("The Contracting States shall apply the provisions of this Convention to refugees without discrimination as to race, religion or country of origin"5), non-penalization ("The Contracting States shall not impose penalties, on account of their illegal entry or presence, on refugees who, coming directly from a territory where their life or freedom was threatened in the sense of article 1 , enter or are present in their territory without authorization, provided they present themselves without delay to the authorities and show good cause for their illegal entry or presence" ${ }^{\prime \prime}$ ) and nonrefoulment ("No Contracting State shall expel or return - <refouler> - a refugee in any manner whatsoever to the frontiers of territories where his life or freedom would be threatened on account of his race, religion, nationality, membership of a particular social group or political opinion"7).

In what concerns the preoccupation towards refugees in the European states, two mechanisms need to be taken into consideration, namely the Council of Europe, with its European Convention on Human Rights and its European Court of Human Rights, and the European Union, with its treaties, its Fundamental Charter and its Court of Justice.

The European Convention on Human Rights does not contain a specific article regarding refugees, a "right of asylum." However, the European Court of Human Rights expanded, through its jurisprudence, the protection of the rights recognized in the Convention even upon refugees. Especially in what regards Article 3 of the ECHR (prohibition on torture and inhuman or degrading treatment or punishment), but also in terms of Article 2 (right to life), Article 6 (right to a fair trial), Article 7 (freedom from retroactive criminal offences and punishment), Article 8 (right to respect for family and private life) etc., the Court argued that it does have competence over asylum cases, regardless of whether there is or isn't a specific right to asylum in the text of the Convention, which led, in such cases, to what is deemed as a form of extraterritorial application of the Convention. Ever since the famous case of Soering v. The United Kingdom, 1989 (and restated in cases such as Cruz Varaz and others v. Sweden, 1991, Vilvarajah v. The United Kingdom, 1991, Chalal v. The United Kingdom, 1995, Saadi v. Italy, 2008, and many others), the Court affirmed and reaffirmed that, although the member states are not held liable for committing a direct breach of the Convention, they

\footnotetext{
${ }^{1}$ Convention relating to the Status of Refugees, Geneva, 28 July 1958, Article 1 (A) (2).

${ }^{2}$ Ibidem.

${ }^{3}$ Ibidem, Article 1 (B) (1).

4 Official data provided by the United Nations High Commissioner for Refugees, http://www.unhcr.org/3b73b0d63.html.

${ }^{5}$ Convention relating to the Status of Refugees, Geneva, 28 July 1958, Article 3.

${ }^{6}$ Ibidem, Article 31.

${ }^{7}$ Ibidem, Article 33.
} 
can be indirectly held liable for removing an alien on the territory of a state in which the rights provided for in the Convention are at risk of being breached. This rationale gave birth to what is known as "protection par ricochet', and applies regardless of the form of removal" - extradition, expulsion and so on, as the Court stated in the aforementioned judgments. But the vast jurisprudence of the European Court of Human Rights in the field had larger effects than the individual decisions - it influenced the practice of European states in what concerns the treatment of aliens and clarified how the obligations of states towards them should be interpreted, and it also highly influenced the manner in which the European Union, as an institution, as well as its specific mechanisms, were to deal with the issue of asylum.

In what concerns the European Union and the previous Communities, the preoccupation for fundamental human rights is rather a recent one, the constitutive treaties of the European Communities recognizing only liberties such as the free movements of goods, capital and persons and the free delivery of services, therefore liberties related to the economic field, ${ }^{9}$ far from representing "fundamental rights" or translating an interest in the human being as such. However, the Treaty of Maastricht does provide for the commitment of the European Union to respect fundamental rights: "The Union shall respect fundamental rights, as guaranteed by the European Convention for the Protection of Human Rights and Fundamental Freedoms signed in Rome on 4 November 1950 and as they result from the constitutional traditions common to the Member States, as general principles of Community law"10 - also establishing, thus, a commitment towards the European Convention on Human Rights. The Treaty of Amsterdam adds that "The Union is founded on the principles of liberty, democracy, respect for human rights and fundamental freedoms, and the rule of law, principles which are common to the Member States"11 (hence, these principles are now fundamental ones), and includes a mechanism for sanctioning the member states that breach these rights and freedoms, and even conditions the accession to the EU by the observance of human rights. Therefore, the preoccupation for the field of human rights, also proved by the possibility of the Court of Justice to refer to such issues (to breaches of the F.2 Article), increased considerably. The adoption of the Charter of Fundamental Rights of the European Union (in Nice, December 7, 2000, within the same European Council as the Treaty of Nice) and granting it the status of legally binding on the EU institutions and on the governments of the member states (through the Treaty of Lisbon), as well as the steps towards the accession of the EU to the European Convention of Human Rights lead to believe that, in the past two decades, the EU is trying to transform respect for human rights into a much more significant issue in the Union. Until this accession, the Charter specifically provides that 'In so far as this Charter contains rights which correspond to rights guaranteed by the Convention for the Protection of Human Rights and Fundamental Freedoms, the meaning and scope of those rights shall be the same as those

\footnotetext{
${ }^{8}$ Frédéric Sudre et al., Marile hotărâri ale Curții Europene a Drepturilor Omului [The great decisions of the European Court for Human Rights] (Iaşi: Editura Polirom, 2006), 134-135.

${ }^{9}$ Jean-François Renucci, Tratat de drept european al drepturilor omului [Traité de Droit européen des droits de l'homme] (Bucharest: Editura Hamangiu, 2009), 18.

${ }^{10}$ Treaty on European Union, Maastricht, 7 February 1992, Article F.2

11 Treaty of Amsterdam amending the Treaty on European Union, the Treaties establishing the European Communities and certain related acts, Amsterdam, 2 October 1997, Article 1.8 (a)
} 
laid down by the said Convention"12 - which leads some to state that "the ECHR is partially incorporated in the Charter and thus in EU primary law."13

In what concerns the issue of the refugees, the consolidated version of the Treaty on the Functioning of the European Union states, in Title V - "Area of Freedom, Security and Justice" that "The Union shall develop a common policy on asylum, subsidiary protection and temporary protection with a view to offering appropriate status to any third-country national requiring international protection and ensuring compliance with the principle of non-refoulement. This policy must be in accordance with the Geneva Convention of 28 July 1951 and the Protocol of 31 January 1967 relating to the status of refugees, and other relevant treaties." ${ }^{\prime 4}$ Continuing the preoccupation in the field that started with the Treaty of Amsterdam, various Directives and Regulations are specifically designed to ensure a Common European Asylum System: Council Directive 2005/85/EC of 1 December 2005, Directive 2013/32/EU of the European Parliament and of the Council of 26 June 2013 (recast), Council Directive 2003/9/EC of 27 January 2003, Directive 2013/33/EU of the European Parliament and of the Council of 26 June 2013 (recast), Council Directive 2004/83/EC of 29 April 2004, Directive 2011/95/EU of the European Parliament and of the Council of 13 December 2011 (recast), Council Regulation (EC) No 343/2003 of 18 February 2003, also known as Dublin II, Regulation (EU) No 604/2013 of the European Parliament and of the Council of 26 June 2013, also known as Dublin III etc.

The 1951 Geneva Convention plays a highly important role in the application of these documents: for instance, the Qualification Directive 2004/83/EC applied to many of those in need of subsidiary protection but who were not Geneva Convention refugees, while the Dublin II Regulation refers only to those who seek Geneva Convention refugee status. ${ }^{15}$

Moreover, the Charter of Fundamental Rights of the European Union specifically provides for a right of asylum, unlike the ECHR, right that "shall be guaranteed with due respect for the rules of the Geneva Convention of 28 July 1951 and the Protocol of 31 January 1967 relating to the status of refugees and in accordance with the Treaty on European Union and the Treaty on the Functioning of the European Union." 16

The Court of Justice of the European Union only obtained full competence in matters of asylum through the Treaty of Lisbon, which abolished the restrictions provided for in the Treaty of Amsterdam in the field, ${ }^{17}$ and that explains why the preoccupation of the Court of Justice in this matter was only noticeable ever since 2009-2010. The ECHR had fulfilled the role of dealing with asylum seekers and refugees through the "protection par ricochet," yet, in recent years, the Court of Justice continues and completes the work of the ECHR, especially through the mechanism of preliminary rulings.

\footnotetext{
${ }^{12}$ Charter of Fundamental Rights of the European Union (2012/C 326/02), Article 52.3

${ }^{13}$ W. Weiß, "Human Rights in the EU: Rethinking the Role of the European Convention on Human Rights After Lisbon", 7 European Constitutional Law Review (2011) 1: 70, quoted in L. Lavrysen, "The European Asylum Law and the ECHR: An Uneasy Coexistence", in Goettingen Journal of International Law 4 (2012) 1: 222.

${ }^{14}$ Consolidated version of the Treaty on the Functioning of the European Union, Article 78

15 Nuala Mole and Catherine Meredith, Asylum and the European Convention on Human Rights (Council of Europe Publishing: 2010), 79, http://www.refworld.org/pdfid/4ee9b0972.pdf (accessed January 15, 2016).

${ }^{16}$ Charter of Fundamental Rights of the European Union (2012/C 326/02), Article 18.

${ }^{17}$ For details, see Marie de Somer, Enhanced competences for the European Court of Justice: "Re-shuffling” the dynamics of EU migration policy-making?, London School of Economics Migrations Study Unit Working Papers no. 2012/01 (London: London School of Economics and Political Science, 2012), 11, http://www.lse.ac.uk/government/research/resgroups/MSU/documents/workingPapers/WP_2012_01.pdf (accessed January 15, 2016).
} 


\section{Relevant Case-law of the Court of Justice of the European Union}

The European Court of Human Rights was and still is often inquired in issues regarding the application of EU pieces of legislation. The Dublin II Regulation, which stated that responsibility for examining the asylum claim belonged to the first European Union country in which the asylum seeker enters, was particularly targeted, since it determined serious issues regarding the transfers back to the states of entry, seen by numerous plaintiffs as breaches of Article 3 of the European Convention on Human Rights. As mentioned before, the ECtHR has been highly sensitive to issues regarding Article 3 , hence it heard and ruled on multiple cases involving possible breaches, even caused by the application of EU pieces of legislation, and its jurisprudence in the field, developed over more than two decades, influenced considerably the jurisprudence of the CJEU. Although it seems that the ECtHR is still the preferred European court to rule in matters related to asylum (if only we take into consideration the number of cases brought in front of the two), the case-law of the CJEU did bring important developments in the field.

One of the first groundbreaking judgments of the Court of Justice (at that point, of the European Communities) in the field of asylum was given in the Elgafaji case, ${ }^{18}$ a request for preliminary ruling regarding the Qualification Directive, Directive 2004/83/EC of 29 April 2004. On 13 December 2006, Mr. and Mrs. Elgafaji submitted applications for temporary residence permits in the Netherlands, together with evidence seeking to prove the real risk to which they would be exposed if they were expelled to their country of origin (Irak), relying, in particular, on fact relating to their personal circumstances (for instance, they pointed out that Mr. Elgafaji's uncle, employed by the same British firm where Mr. Elgafaji was working, had been killed by militia, his death certificate stating that his death followed a terrorist act. A short time later, a letter threatening "death to collaborators" was fixed to the door of the residence which Mr. Elgafaji shared with his wife, a Sunni Muslim). Mr. and Mrs. Elgafaji requested temporary residence permits in the Netherlands, which was refused by the competent authorities, on grounds that the two had not proved satisfactorily the circumstances on which they were relying and, therefore, had not established the real risk of serious and individual threat to which they claimed to be exposed in their country of origin ${ }^{19}$. The applicants brought actions against this decision, and the Hague District Court they had addressed to decided in their favour. On appeal, however, the Council of State held that there were difficulties in interpreting the relevant provisions of the Qualification Directive. It held, furthermore, that Article 15(c) of the Directive had not been transposed into Netherlands law by 20 December 2006, the date on which the Minister's contested orders were made. ${ }^{20}$ Article 15 of the mentioned Directive, under Chapter V - Qualification for subsidiary protection - refers to serious harm, and defines it as "(a) death penalty or execution; or (b) torture or inhuman or degrading treatment or punishment of an applicant in the country of origin; or (c) serious and individual threat to a civilian's life or person by reason of indiscriminate violence in situations of international or internal armed conflict." The Minister for Immigration and Integration, which had denied the residence permit, argued that the standard of proof required for the protection granted under Article 15(b) of the Directive is identical to that required for the protection granted under Article 15(c), and therefore the applicants are required to show satisfactorily, in their individual circumstances, the risk of serious and individual threat to which they would be exposed were they to

\footnotetext{
18 Judgment of the Court of Justice in Case C-465/07 Meki Elgafaji and Noor Elgafaji v. Staatssecretaris van Justitie, 17 February 2009.

${ }^{19}$ Ibidem, par. 17-19.

${ }^{20}$ Ibidem, par. 21-25.
} 
be returned to their country of origin. The Hague District Court considered, however, that Article 15(c) of the Directive takes into consideration the existence of armed conflict in the country of origin of the applicant seeking protection, and does not require the high degree of individualisation of the threat required by Article 15(b) of the Directive and by the subsequent article of national legislation through which this provision transposed. Therefore, in the opinion of the Hague District Court, 'the existence of a serious and individual threat to the persons seeking protection can be proved more easily under Article 15(c) of the Directive than under Article 15(b)', and, in the given situation, 'the proof required under Article 15(c) of the Directive had been aligned with that required in the application of Article 15(b) of the Directive. ${ }^{21}$

In those circumstances, the Council of State, on appeal, decided to stay proceedings and to refer two questions to the Court of Justice for a preliminary ruling. First of all, it asked whether Article 15(c) is to be interpreted as offering protection only in a situation in which Article 3 of the ECHR, as interpreted in the case-law of the European Court of Human Rights, also has a bearing, or whether Article 15(c), in comparison with Article 3 of the ECHR, offers, in fact, supplementary or other protection. Secondly, the Council of State asked, in the event that Article 15(c), in comparison with Article 3 of the ECHR, does offer supplementary or other protection, what are the criteria for determining whether a person who claims to be eligible for subsidiary protection status runs a real risk of serious and individual threat by reason of indiscriminate violence within the terms of Article 15(c) of the Directive, read in conjunction with Article 2(e). ${ }^{22}$ This Article defines a "person eligible for subsidiary protection' as 'a third country national or a stateless person who does not qualify as a refugee (defined in Article 2(c) of the same Directive - N/N), but in respect of whom substantial grounds have been shown for believing that the person concerned, if returned to his or her country of origin (...) would face a real risk of suffering serious harm as defined in Article 15, and to whom Article 17(1) and (2) do not apply, and is unable, or, owing to such risk, unwilling to avail himself or herself of the protection of that country."

The Court of Justice clarified that, "while the fundamental right guaranteed under Article 3 of the ECHR forms part of the general principles of Community law, observance of which is ensured by the Court, and while the case-law of the European Court of Human Rights is taken into consideration in interpreting the scope of that right in the Community legal order, it is, however, Article 15(b) of the Directive which corresponds, in essence, to Article 3 of the ECHR. By contrast, Article 15(c) of the Directive is a provision the content of which is different from that of Article 3 of the ECHR, and the interpretation of which must, therefore, be carried out independently, although with due regard for fundamental rights, as they are guaranteed under the ECHR."23

After carefully analyzing the three types of "serious harm" defined in Article 15 of the Directive, which constitute the qualification for subsidiary protection, the Court of Justice decided that Article 15(c), in conjunction with Article 2(e), must be interpreted as meaning that (1) "the existence of a serious and individual threat to the life or person of an applicant for subsidiary protection is not subject to the condition that that applicant adduce evidence that he is specifically targeted by reason of factors particular to his personal circumstances" and that (2) "the existence of such a threat can exceptionally be considered to be established where the degree of indiscriminate violence characterising the armed conflict taking place (...) reaches such a high level that substantial grounds are shown for believing that a civilian, returned to the relevant country or, as the case may be, to the

\footnotetext{
${ }^{21}$ Ibidem, par. 20, 23, 24.

${ }^{22}$ Ibidem, par. 26.

${ }^{23}$ Ibidem, par. 28.
} 
relevant region, would, solely on account of his presence on the territory of that country or region, face a real risk of being subject to that threat." ${ }^{24}$ Hence, the Court assessed that an applicant for subsidiary protection (one who does not fall within the 'refugee' definition, according to Article 2(c) of the Qualification Directive) is not necessarily required to prove that the is specifically targeted in his country of origin due to his personal circumstances, and the degree of indiscriminate violence in the applicant's country of origin can be enough reason to believe that, if returned to that country, he/she would face a real risk of being subjected to serious individual threat.

Regarding the same Qualification Directive (Directive 2004/83/EC), the Court gave an interpretation of the conditions required by the 1951 Geneva Convention for the status of refugee to be granted, in the Bolbol case, ${ }^{25}$ also a request for a preliminary ruling. Ms. Bolbol, after leaving the Gaza Strip in the company of her husband, arrived in Hungary on 10 January 2007, with a visa. She was granted a residence permit from the immigration authority. On 21 June 2007 she submitted an application for asylum to the Office for Immigration and Citizenship in Hungary, invoking the unsafe situation in the Gaza Strip caused by the daily clashes between Fatah and Hamas. The ground for her request was Article 1D, the second subparagraph, of the Geneva Convention, pointing out that she was a Palestinian residing outside UNRWA's area of operations (United Nations Relief and Works Agency for Palestine Refugees in the Near East - N/N). However, it seemed, despite the steps taken by Ms. Bolbol at UNRWA, that she had not availed herself of the protection or assistance of UNRWA, and her right to be registered on the basis of her family connections had been unable to confirm. ${ }^{26}$ Article 1D of the Geneva Convention, in its first subparagraph, states that the Convention "shall not apply to persons who are at present receiving from organs or agencies of the United Nations other than the United Nations High Commissioner for Refugees protection or assistance," and, in its second subparagraph, that Ms. Bolbol invoked, states that, "when such protection or assistance has ceased for any reason, without the position of such persons being definitively settled in accordance with the relevant resolutions adopted by the General Assembly of the United Nations, these persons shall ipso facto be entitled to the benefits of this Convention."

Ms. Bolbol has requested the referring court to vary the negative decision received from the Office for Immigration and Citizenship, and to grant her refugee status pursuant to the second subparagraph of Article 1D of the Geneva Convention. In her view, this Article is a separate basis for recognition as a refugee and, since she meets the conditions laid down in that provision, she is entitled to recognition as a refugee irrespective of whether she qualifies as a refugee under Article 1A. The purpose of Article 1D, as Bolbol sees it, is to make clear that, when a person registered or entitled to be registered with UNRWA resides, for any reason, outside UNRWA's area of operations, and, for good reason, cannot be expected to return there, the States party to the Geneva Convention must automatically grant him/her refugee status. In view of the fact that, through her father, she is entitled to be registered with UNRWA, but resides outside its area of operations (in Hungary), she should be recognised as a refugee without further examination. ${ }^{27}$ The Office for Immigration and Citizenship, however, argued that Ms. Bolbol did not leave her country for any of the reasons set out in Article 1A of the Geneva Convention, and that Article 1D does not automatically grant a basis for refugee status, hence Palestinians are entitled to refugee status only where they meet the definition of "refugee" within the

\footnotetext{
${ }^{24}$ Ibidem, Ruling .

25 Judgment of the Court of Justice (Grand Chamber) in Case C-31/09 Nawras Bolbol v Bevándorlási és Állampolgársági Hivatal, 17 June 2010.

${ }^{26}$ Ibidem, par. 25-27.

${ }^{27}$ Ibidem, par. 31.
} 
meaning of Article 1A of the Geneva Convention, which must be determined on a case-by-case basis. ${ }^{28}$

The referring court, the Budapest Municipal Court, assessed that, due to the lack of clarity of Article 1D of the Geneva Convention, and due to the fact that the Qualification Directive includes a reference to Article 1D in its own Article 12(1)(a), ${ }^{29}$ the Court of Justice had jurisdiction to interpret the meaning of this specific Article from the 1951 Convention. Therefore, it asked the Court for a preliminary ruling in the matter, in order to clarify, among others, whether, for the purposes of Article 12(1)(a) of Council Directive 2004/83/EC, someone must be regarded as a person receiving the protection and assistance of a United Nations agency merely by virtue of the fact that he is entitled to assistance or protection, or is it also necessary for him to actually avail himself of that protection or assistance (and what does "cessation of the agency's protection or assistance" mean). ${ }^{30}$

The Court of Justice (now, of the European Union) stated, first of all, that the Qualification Directive was adopted on the basis of, among others, Article 63 EC (current Article 78 TFUE - N/N), which required the Council of the European Union to adopt measures on asylum, in accordance with the Geneva Convention and other relevant treaties, within the area of minimum standards with respect to the qualifications of nationals of third countries as refugees. Also, the Court considers that "the Geneva Convention constitutes the cornerstone of the international legal regime for the protection of refugees, and the provisions of the Directive must be interpreted in the light of its general scheme and purpose," while respecting the Geneva Convention and the other relevant treaties referred to in point (1) of the first subparagraph of Article $63 \mathrm{EC}$ - "Those provisions must also (...) be interpreted in a manner which respects the fundamental rights and the principles recognised in particular by the Charter of Fundamental Rights of the European Union." ${ }^{\text {31 }}$ As to the questions raised by the referring Hungarian court, the Court of Justice stated that Article 1D of the Geneva Convention, to which Article 12(1)(a) of the Directive refers, merely excludes from the scope of that convention those persons who are "at present receiving" protection or assistance from an organ or agency of the United Nations other than UNHCR - hence, "only those who have actually availed themselves of the assistance provided by UNRWA come within the clause excluding refugee status set out therein, which must, as such, be construed narrowly and cannot therefore also cover persons who are or have been eligible to receive protection or assistance from that agency." Moreover, while registration with UNRWA is sufficient proof of actually receiving assistance from it (...), such assistance can be provided even in the absence of such registration, in which case the beneficiary must be permitted to adduce evidence of that assistance by other means ${ }^{132}$ - while it was clear that Ms. Bolbol had not availed herself of protection or assistance from the UNRWA. Therefore, the ruling of the Court was that, "for the purposes of the first sentence of Article 12(1)(a) of Council Directive 2004/83/EC (...), a

\footnotetext{
${ }^{28}$ Ibidem, par. 32.

29 'A third country national or a stateless person is excluded from being a refugee, if: (a) he or she falls within the scope of Article $1 \mathrm{D}$ of the Geneva Convention, relating to protection or assistance from organs or agencies of the United Nations other than the United Nations High Commissioner for Refugees. When such protection or assistance has ceased for any reason, without the position of such persons being definitely settled in accordance with the relevant resolutions adopted by the General Assembly of the United Nations, these persons shall ipso facto be entitled to the benefits of this Directive' - Directive 2004/83/EC, Article 12 (1)(a).

30 Judgment of the Court of Justice (Grand Chamber) in Case C-31/09 Nawras Bolbol v Bevándorlási és Állampolgársági Hivatal, 17 June 2010, par. 35.

${ }^{31}$ Ibidem, 36-38.

${ }^{32}$ Ibidem, par. 50-52.
} 
person receives protection or assistance from an agency of the United Nations other than UNHCR when that person has actually availed himself of that protection or assistance." 33

Another important judgment was issued by the Court in what concerns Article 12 of the Qualification Directive. In the Joined Cases B and D, ${ }^{34}$ where B and D were Turkish nationals of Kurdish origin, the issue raised was that of Article 12 (2) (b) and (c), stating that "A third country national or a stateless person is excluded from being a refugee where there are serious reasons for considering that: (...) (b) he or she has committed a serious non-political crime outside the country of refuge prior to his or her admission as a refugee; which means the time of issuing a residence permit based on the granting of refugee status; particularly cruel actions, even if committed with an allegedly political objective, may be classified as serious non-political crimes; (c) he or she has been guilty of acts contrary to the purposes and principles of the United Nations as set out in the Preamble and Articles 1 and 2 of the Charter of the United Nations."

B. entered Germany at the end of 2002, where he applied for asylum and for protection as a refugee and, in the alternative, for an order prohibiting his deportation to Turkey. To support his application, B stated, inter alia, that, in Turkey, he had been a sympathiser of Dev Sol (now DHKP/C) when he was still in school and that, from the end of 1993 until the beginning of 1995, he had supported armed guerrilla warfare in the mountains. Being arrested in February 1995, he had been subjected to serious physical abuse and had been forced to give a statement under torture, hence was sentenced to life imprisonment in December 1995. In 2001, while he was in custody, B received another life sentence after confessing to having killed a fellow prisoner suspected of being an informant. Taking advantage of a six-month conditional release from custody on health grounds, he left Turkey and arrived in Germany in December 2002. ${ }^{35}$

D. has resided in Germany since May 2001, and, on 11 May 2001, he applied for asylum. He stated, among others, that, in 1990, he had fled to the mountains, where he joined the PKK. He had been a guerrilla fighter for the PKK and one of its senior officials and, at the end of 1988, the PKK had sent him to northern Iraq. D had left the PKK in May 2000 because of political differences with its leadership, and since then had been under threat. He had stayed on in northern Iraq for about one more year, but had not been safe there. He was granted asylum in May 2011, and was recognized as a refugee, but a change in national law made it possible for the favourable decision to be overturned. ${ }^{36}$

Responding by preliminary ruling to the questions raised by the Federal Republic of Germany regarding the application of Article 12 (2) (b) and (c), the Court of Justice stated that this article must be interpreted as meaning, first of all, that the fact that a person has been a member of an organisation which (because of its involvement in terrorist acts) is on the list forming the Annex to Common Position 2001/931/CFSP (...) and that that person has actively supported the armed struggle waged by that organisation does not automatically constitute a serious reason for considering that that person has committed "a serious non-political crime" or "acts contrary to the purposes and principles of the United Nations." Second of all, the finding, in such a context, that there are serious reasons for considering that a person has committed such a crime or has been guilty of such acts is conditional on an assessment on a case-by-case basis of the specific facts, with a view to determining whether the acts committed by the organisation concerned meet the conditions laid down in those provisions and

\footnotetext{
${ }^{33}$ Ibidem, Ruling.

${ }^{34}$ Judgment of the Court of Justice (Grand Chamber) in Joined Cases of C-57/09 Bundesrepublik Deutschland $v$ B and C-101/09 Bundesrepublik Deutschland v D, 9 November 2010.

${ }^{35}$ Ibidem, par. 43-48.

${ }^{36}$ Ibidem, par. 56-63.
} 
whether individual responsibility for carrying out those acts can be attributed to the person concerned, regard being had to the standard of proof required under Article 12(2) of the directive'. Moreover, the Court stated that "exclusion from refugee status pursuant to Article 12(2)(b) or (c) of Directive 2004/83 is not conditional on the person concerned representing a present danger to the host Member State', nor on 'an assessment of proportionality in relation to the particular case." 37

After the judgment of the European Court of Human Rights in the M.S.S. case (M.S.S. v. Belgium and Greece, Grand Chamber European Court of Human Rights Judgment of January 21, 2011), through which the ECtHR condemned the automatic application of the Dublin Regulation by Member States for determining which Member State was responsible for examining the asylum application, the Court of Justice was asked to take over the case law from Strasbourg in the judgment of N.S. of December 21, 2011 regarding the Dublin Regulation, in order to provide some general guidance on EU asylum policy, on the basis of Article 18 of the EU Charter of Fundamental Rights and Article 78 of the TFEU (which states that a common European asylum system should be based on full compliance with the Geneva Convention) ${ }^{38}$. The ECtHR decided that the Belgian authorities should not have expelled M.S.S., an asylum seeker, to Greece, in light of the fact that, according to Dublin II, Greece was the first country of entry of the applicant within the European Union, and was thus charged with the decision of granting asylum or not to the applicant. Among others, the ECtHR condemned both the deficiencies in the asylum procedures (breaches of Article 13 ECHR) and detention and living conditions (amounting to breaches of Article 3 ECHR) in Greece, and the decision of Belgium to send him back to Greece, for having exposed him to these conditions (the reaction of Belgium also amounting to a breach of Article 3).

Therefore, in Joined Cases N.S. and M.E. and others, ${ }^{39}$ the Court of Justice of the European Union was asked for a preliminary ruling regarding Article 3(2) of Council Regulation (EC) No 343/2003 of 18 February 2003 (Regulation Dublin II), the fundamental rights of the European Union, including the rights set out in Articles 1, 4, 18, 19(2) and 47 of the Charter of Fundamental Rights of the European Union, and Protocol (No 30) on the application of the Charter to Poland and to the United Kingdom. These two references have been made in proceedings that took place between asylum seekers who were to be returned to Greece pursuant to Regulation No 343/2003 and the United Kingdom (N.S.) and Irish authorities (M.E. and others). ${ }^{40}$

N.S. was an Afghan national who came to the United Kingdom after travelling through, among other countries, Greece. He was arrested in Greece on 24 September 2008, but did not make an asylum application. He claimed that the Greek authorities detained him for four days and, on his release, gave him an order to leave Greece within 30 days; when he tried to leave Greece, he was arrested by the police and was expelled to Turkey, where he was detained in appalling conditions for two months. N.S. states that he escaped from his place of detention in Turkey and travelled from that State to the United Kingdom, where he arrived on 12 January 2009 and where he lodged an asylum application that same day. On 1 April 2009, the Secretary of State for the Home Department made a request to the Hellenic Republic, according to Article 17 of Regulation No 343/2003, to take charge of the appellant

\footnotetext{
${ }^{37}$ Ibidem, Ruling.

38 Henry Labayle and Philippe de Bruycker, The Influence of ECJ and ECtHR case law on asylum and immigration. Study (European Parliament, Directorate-General for Internal Policies, Policy Department C, Citizens' Rights and Constitutional Affairs: 2012), 4, http://www.europarl.europa.eu/RegData/etudes/etudes/join/ 2012/462438/IPOL-LIBE_ET(2012)462438(SUM01)_EN.pdf (accessed January 15, 2016).

${ }^{39}$ Judgment of the Court of Justice (Grand Chamber) in Joined Cases of C-411/10 N.S. v The United Kingdom and C-493/10 M.E. and others v Ireland, 21 December 2011.

${ }^{40}$ Ibidem, par. $1-2$
} 
in the main proceedings in order to examine his asylum application. Since the Hellenic Republic failed to respond to that request within the time limit stipulated by Article 18(7) of the Regulation, it was accordingly deemed to have accepted responsibility for examining the appellant's claim, pursuant to that provision, on June 18, 2009. His further attempts at preventing this situation have been denied, however, judicial review of the last refusal he had received was granted, and he eventually received the right to appeal to the Court of Appeal, England \& Wales, Civil Division. ${ }^{41}$ This Court was aware that asylum procedures in Greece are said to have serious shortcomings (applicants encounter numerous difficulties in carrying out the necessary formalities; they are not provided with sufficient information and assistance; their claims are not examined with due care), that the proportion of asylum applications which are granted is extremely low, that judicial remedies are stated to be inadequate and very difficult to access, and that the conditions for reception of asylum seekers are considered to be inadequate: applicants are either detained in inadequate conditions or they live outside in destitution, without shelter or food. ${ }^{42}$ Therefore, the previously mentioned Court of Appeal requested a preliminary ruling on whether a decision made by a Member State under Article 3(2) of Regulation $343 / 2003^{43}$ to examine a claim for asylum which is not its responsibility according to Chapter III of the Regulation falls within the scope of EU law for the purposes of Article 6 [TEU] and/or Article 51 of the Charter; if so, the Court of Appeal asked, among others, whether the duty of a Member State to observe EU fundamental rights (including the rights set out in Articles 1, 4, 18, 19(2) and 47 of the Charter) is discharged where that State sends the asylum seeker to the Member State which Article 3(1) of Regulation No 343/2003 designates as the responsible State in accordance with the criteria set out in Chapter III of the regulation ("the responsible State"), regardless of the situation in the responsible State. ${ }^{44}$

As for M.E. and the other four appellants in the national proceedings, each of them (unconnected with each other) travelled via Greece and were arrested for illegal entry. They then travelled to Ireland, where they claimed asylum. Each of them resisted the return to Greece, not invoking Article 3 ECHR, but claiming that the procedures and conditions for asylum seekers in Greece are "inadequate" and that "Ireland is therefore required to exercise its power under Article 3(2) of Regulation No 343/2003 to accept responsibility for examining and deciding on their asylum claims." The High Court requested a preliminary ruling on whether the transferring Member State under Regulation (EC) No 343/2003 is obliged to assess the compliance of the receiving Member State with Article 18 of the Charter, and documents such as Directives 2003/9/EC, 2004/83/EC and 2005/85/EC and Regulation (EC) No $343 / 2003$, and, if the answer is positive, and if the receiving Member State is found not to be in

\footnotetext{
${ }^{41}$ Ibidem, par. 34-43.

${ }^{42}$ Ibidem, par. 44.

${ }^{43}$ Article 3 states, in its first two paragraphs, that: '

1. Member States shall examine the application of any third-country national who applies at the border or in their territory to any one of them for asylum. The application shall be examined by a single Member State, which shall be the one which the criteria set out in Chapter III indicate is responsible.

2. By way of derogation from paragraph 1, each Member State may examine an application for asylum lodged with it by a third-country national, even if such examination is not its responsibility under the criteria laid down in this Regulation. In such an event, that Member State shall become the Member State responsible within the meaning of this Regulation and shall assume the obligations associated with that responsibility. Where appropriate, it shall inform the Member State previously responsible, the Member State conducting a procedure for determining the Member State responsible or the Member State which has been requested to take charge of or take back the applicant'.

${ }^{44}$ Judgment of the Court of Justice (Grand Chamber) in Joined Cases of C-411/10 N.S. v The United Kingdom and C-493/10 M.E. and others $v$ Ireland, 21 December 2011, par. 50.
} 
compliance with one or more of those provisions, the transferring Member Sate is obliged to accept responsibility for examining the application under Article 3(2) of Regulation (EC) No 343/2003. ${ }^{45}$

The Court of Justice ruled, first of all, that the decision adopted by a Member State according to Article 3(2) of Council Regulation (EC) No 343/2003 whether to examine an asylum application which is not its responsibility according to the criteria laid down in Chapter III of that Regulation does implement European Union law for the purposes of Article 6 TEU and/or Article 51 of the Charter of Fundamental Rights of the European Union. Secondly, the Court stated that European Union law "precludes the application of a conclusive presumption that the Member State which Article 3(1) of Regulation No 343/2003 indicates as responsible observes the fundamental rights of the European Union." Therefore, the Court ruled, in a groundbreaking formulation for EU law, that "Article 4 of the Charter of Fundamental Rights of the European Union must be interpreted as meaning that the Member States, including the national courts, may not transfer an asylum seeker to the "Member State responsible" within the meaning of Regulation No 343/2003 where they cannot be unaware that systemic deficiencies in the asylum procedure and in the reception conditions of asylum seekers in that Member State amount to substantial grounds for believing that the asylum seeker would face a real risk of being subjected to inhuman or degrading treatment within the meaning of that provision." Moreover, "subject to the right itself to examine the application referred to in Article 3(2) of Regulation No 343/2003, the finding that it is impossible to transfer an applicant to another Member State, where that State is identified as the Member State responsible in accordance with the criteria set out in Chapter III of that regulation, entails that the Member State which should carry out that transfer must continue to examine the criteria set out in that chapter in order to establish whether one of the following criteria enables another Member State to be identified as responsible for the examination of the asylum application." Hence, "the Member State in which the asylum seeker is present must ensure that it does not worsen a situation where the fundamental rights of that applicant have been infringed by using a procedure for determining the Member State responsible which takes an unreasonable length of time. If necessary, the first mentioned Member State must itself examine the application in accordance with the procedure laid down in Article 3(2) of Regulation No 343/2003."46

The argument seems to "continue" in the Kaveh Puid Case, ${ }^{47}$ the Court stating that, "where the Member States cannot be unaware that systemic deficiencies in the asylum procedure and in the conditions for the reception of asylum seekers in the Member State initially identified as responsible in accordance with the criteria set out in Chapter III of Council Regulation (EC) No 343/2003 (...) provide substantial grounds for believing that the asylum seeker concerned would face a real risk of being subjected to inhuman or degrading treatment within the meaning of Article 4 of the Charter of Fundamental Rights of the European Union (...), the Member State which is determining the Member State responsible is required not to transfer the asylum seeker to the Member State initially identified as responsible and, subject to the exercise of the right itself to examine the application, to continue to examine the criteria set out in that chapter, in order to establish whether another Member State can be identified as responsible in accordance with one of those criteria or, if it cannot, under Article 13 of the Regulation. Conversely, in such a situation, a finding that it is impossible to transfer an asylum seeker to the Member State initially identified as responsible does not in itself mean that the Member

\footnotetext{
${ }^{45}$ Ibidem, par. 51-53.

46 Ibidem, Ruling.

47 Judgment of the Court of Justice (Grand Chamber) in Case C-4/11 Bundesrepublik Deutschland v Kaveh Puid, 14 November 2013.
} 
State which is determining the Member State responsible is required itself, under Article 3(2) of Regulation No 343/2003, to examine the application for asylum." 48

\section{Conclusion}

It is fair to assess that the European Court of Human Rights played a major role in the development of the standards applicable to asylum seekers and individuals requesting subsidiary protection, in spite of the lack of a 'right of asylum' in the European Convention. Especially the 'protection par ricochet' granted in what concerns breaches of Article 3 (including if such breaches came from the application of important pieces of EU legislation) determined a more careful consideration by the states that are member to the EU as well - it is sufficient to consider the fact that the judgment in the M.S.S. case led many European states to suspend the application of the Dublin system in what concerns Greece. However, the ECtHR has an experience of over 25 years in the field, unlike the CJEU, and this amount of time also granted it the trust of the applicants - an area in which the CJEU might still need to work.

The Court of Justice of the European Union assumed the role of dealing with human rights in general and the right of asylum in particular in a serious manner, following the lead of ECtHR, but having the Charter of Fundamental Freedoms at hand. The fact that the Charter does contain a specific provision for the right to asylum, although perhaps not invoked often enough (and the referring courts may be to blame in this issue), may give rise to more and more ambitious developments of the EU legislation in matters of asylum and subsidiary protection. Already, the numerous claims against the Qualification Directive and The Dublin II Regulation led to their revision and improvement, as well as of the other directives in this field. That means that the Court of Justice actively participates in the enhancement of EU law regarding asylum, which, if we are to take into consideration the 2015 "refugee crisis," offers enough room for debate and is in need of another serious revision.

Since the two major European courts seem to be in agreement in similar issues brought to their attention, the EU and its Court of Justice pledging allegiance to the European Convention on Human Rights and applying it accordingly, and the EU even acceding to it, the future of the protection granted to vulnerable categories such as asylum seekers does not seem to be in everlasting trouble, as it currently seems. Solutions such as the one adopted towards Greece (who claims to be making efforts towards no longer being considered a "black sheep" in terms of its procedures, detention conditions and so on) could be adopted anytime towards any of the other member states located at the frontiers of the Union - states on which the pressure caused by the increase in number of applicants and enforcement of Dublin system is at least disproportionate to their resources and possibilities. The Court of Justice has a multitude of instruments at hand, both in terms of legislation to be applied and in terms of its authority - it can provide interpretations of legislation through preliminary rulings, it can decide upon breaches of obligations by the member states, it can annul pieces of EU legislation or sanction EU institutions etc. Using these instruments wisely, more precisely, always considering respect for human rights in the centre of its decisions, can highly determine both the protection of the vulnerable and the trust of the potential applicants.

\footnotetext{
${ }^{48}$ Ibidem, Ruling.
} 


\section{References}

Labayle, Henry, and Philippe de Bruycker. The Influence of ECJ and ECtHR case law on asylum and immigration. Study. European Parliament, Directorate-General for Internal Policies, Policy Department C, Citizens' Rights and Constitutional Affairs: 2012, http://www.europarl.europa.eu/RegData/etudes/etudes/join/2012/462438/IPOL-

LIBE_ET(2012)462438(SUM01)_EN.pdf (accessed January 15, 2016).

Lavrysen, L. "The European Asylum Law and the ECHR: An Uneasy Coexistence". In Goettingen Journal of International Law 4 (2012) 1: 217-262

Mole, Nuala, and Catherine Meredith. Asylum and the European Convention on Human Rights. Council of Europe Publishing: 2010, http://www.refworld.org/pdfid/4ee9b0972.pdf (accessed January 15, 2016).

Renucci, Jean-François. Tratat de drept european al drepturilor omului [Traité de Droit européen des droits de l'homme]. București: Editura Hamangiu, 2009.

Somer, Marie de. Enhanced competences for the European Court of Justice: "Re-shuffling" the dynamics of EU migration policy-making?. London School of Economics Migrations Study Unit Working Papers no. 2012/01. London: London School of Economics and Political Science, 2012, http://www.lse.ac.uk/government/research/resgroups/MSU/documents/workingPapers/WP_2012_0 1.pdf (accessed January 15, 2016).

Sudre, Frédéric et al. Marile hotărâri ale Curții Europene a Drepturilor Omului [Les grands arrêts de la Cour européenne des Droits de l'homme]. Iași: Editura Polirom, 2006.

Weiß, W. "Human Rights in the EU: Rethinking the Role of the European Convention on Human Rights After Lisbon". In European Constitutional Law Review 7 (2011) 1: 64-95.

Convention relating to the Status of Refugees, Geneva, 28 July 1958.

Treaty on European Union, Maastricht, 7 February 1992.

Treaty of Amsterdam amending the Treaty on European Union, the Treaties establishing the European Communities and certain related acts, Amsterdam, 2 October 1997.

Charter of Fundamental Rights of the European Union, (2012/C 326/02).

Consolidated version of the Treaty on the Functioning of the European Union.

Judgment of the Court of Justice in Case C-465/07 Meki Elgafaji and Noor Elgafaji v. Staatssecretaris van Justitie, 17 February 2009.

Judgment of the Court of Justice (Grand Chamber) in Case C-31/09 Nawras Bolbol v Bevándorlási és Állampolgársági Hivatal, 17 June 2010.

Judgment of the Court of Justice (Grand Chamber) in Joined Cases of C-57/09 Bundesrepublik Deutschland v B and C-101/09 Bundesrepublik Deutschland v D, 9 November 2010.

Judgment of the Court of Justice (Grand Chamber) in Joined Cases of C-411/10 N.S. v The United Kingdom and C-493/10 M.E. and others v Ireland, 21 December 2011.

Judgment of the Court of Justice (Grand Chamber) in Case C-4/11 Bundesrepublik Deutschland v Kaveh Puid, 14 November 2013. 